\title{
An Analysis of the Lack of Protection for Intangible Tribal Cultural Property in the Digital Age
}

\author{
Chante Westmoreland*
}

\begin{abstract}
This Note analyzes how the current push for digitization of library and museum collections exacerbates the infringement and appropriation of intangible tribal cultural property and how current statutory schemes fail to adequately protect such property. Cultural property includes any sacred traditional knowledge essential to tribal ways of life and is often privileged information. Intangible cultural property is easily likened to intellectual property in import but does not share the same policy rationale. Because intellectual property laws are justified using "incentive-creation" and other utilitarian theories, these laws inadequately protect tribal images, sacred songs, and other types of traditional knowledge. Meanwhile, statutory schemes specific to cultural property focus solely on tangible sacred objects, such as ceremonial and funerary regalia. This leaves items such as photographs, notes, and recordings, which contain culturally sensitive information, exposed to outsiders and ripe for infringement. In order to remedy this harm, Congress should fulfill its fiduciary obligation to tribes by enacting laws that incentivize libraries, museums, and other educational entities to negotiate with tribes to license or repatriate intangible cultural property prior to digitization.
\end{abstract}

Introduction. 960

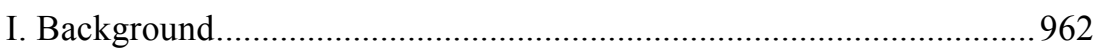

A. The Significance of Cultural Property .................................962

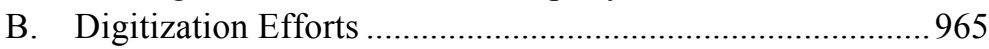

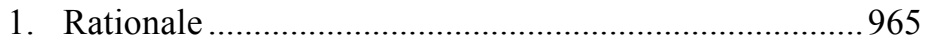

DOI: https://doi.org/10.15779/Z38RV0D11G

Copyright (C) 2018 California Law Review, Inc. California Law Review, Inc. (CLR) is a California nonprofit corporation. CLR and the authors are solely responsible for the content of their publications.

* Chante is a 2018 J.D. candidate at Berkeley Law. I would like to thank Professors Scott Williams, Eric Biber, Lila Bailey, and Sonia Katyal for their feedback and guidance. Special thanks to Roe Bubar for empowering me to find my voice and to the $C L R$ Notes team for their edits. 
2. The Intersection of Digitization and Tribal Cultural

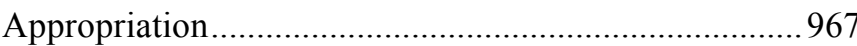

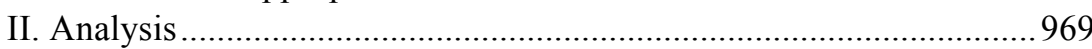

A. The Misfit of Existing Intellectual Property Protection.......969

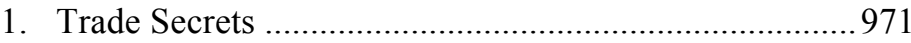

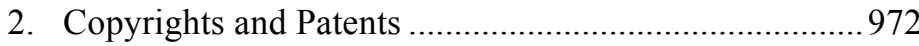

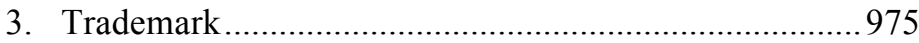

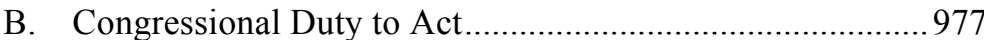

1. Defining Plenary Power............................................... 977

2. Plenary Power as a Tool for Cultural Protection: The Example of The Indian Child Welfare Act.....................978

3. Inadequacy of Existing Tangible Cultural Property Legislation 980

a. The Native American Graves Protection and Repatriation Act ...................................................980

i. Overview of Application...................................980

ii. Repatriate-able Objects ......................................981

b. The Indian Arts and Crafts Act ................................984

c. The National Historic Preservation Act and the Archeological Resources Protection Act .................985

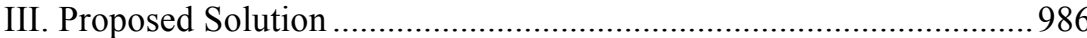

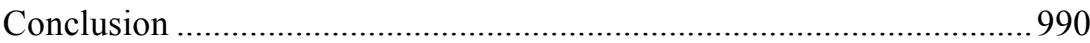

\section{INTRODUCTION}

Libraries, museums, and other educational institutions are prioritizing the digitization of their collections. ${ }^{1}$ Through digitization, these educational entities hope to provide greater remote access to information and preserve items of historical importance, such as photographs, documents, and recordings. Digitization is validated by the widely held American belief that the public has a right to access information, subject to various intellectual property (IP) and privacy rights. However, for historically marginalized groups, wider dissemination may result in an infringement on a collective right to control cultural property.

Educational entities ${ }^{2}$ are notorious for their collections on tribal people, which often consist of tangible objects containing sensitive cultural information. From anthropological journals to photographs to recordings, these objects tend to host a wealth of privileged information never meant to be shared with

1. See, e.g., Preservation Guidelines for Digitizing Library Materials, LIBR. OF CONGRESS, http://www.loc.gov/preservation/care/scan.html [https://perma.cc/Z2CU-VMEP] (explaining the purpose of the library's digitization project).

2. In this Note, "educational entities" refers to federally funded libraries, universities, and museums. 
outsiders. While there are some federal laws that require educational entities to return some types of tangible objects to tribes, ${ }^{3}$ these statutes are imperfect for three reasons. First, these laws provide limited protection to limited categories of objects. Second, these laws do not protect the information contained within a tangible object. In other words, when it comes to cultural objects, federal law does not protect what Western minds would consider to be intellectual property (and what tribes would consider to be the sacred nature of the object); rather, the law only protects the physical item itself. Thus, the sacred information contained by photographs, journals, and recordings are without protection from exploitation by non-tribal members. Last, the laws fall short, even with regard to protectable types of tangible property. Federal law does not prevent educational entities from digitizing or replicating objects before repatriation. Thus, with the rising drive to provide technological access to information, tribal cultural property is at risk of further dissemination and reappropriation.

In light of this gap in protection, policy-makers should enact laws that facilitate negotiations between tribal governments and educational entities to either repatriate or license the use of intangible cultural property.

Federally recognized tribes have a unique relationship with the federal government. The tribes are sovereign nations, but they operate within another sovereign nation. ${ }^{4}$ Thus, while tribes retain the right to regulate their own membership, make their own laws, and operate their own commercial enterprises, they remain subject to Congress's plenary powers. ${ }^{5}$ In exchange, the federal government takes on a supervisory, albeit paternalistic, role. ${ }^{6}$ The federal government has assumed responsibility for the protection and preservation of tribes and their resources, and should therefore take steps to protect tribal cultural property. $^{7}$

To explain the need for regulation, this Note will first define the significance of cultural property, discuss the policy rationale behind digitization, and explain how digitization threatens intangible cultural property. Next, this Note will demonstrate how existing IP law fails to protect intangible cultural

3. See discussion infra Part II.B.3.

4. Frank Pommersheim, Liberation, Dreams, and Hard Work: An Essay on Tribal Court Jurisprudence, 1992 WIS. L. REV. 411, 417 ("One of the legacies of the colonization process is the fact that Indian tribes, which began their interaction with the federal government as largely sovereign entities outside the republic, were increasingly absorbed into the republic, eventually becoming internal sovereigns of a limited kind."); see also ROBERT T. ANDERSON, BETHANY BERGER, SARAH KRAKOFF \& PHILIP P. FRICKEY, AMERICAN INDIAN LAW: CASES AND COMMENTARY 41-42 (3d ed. 2015) [hereinafter AMERICAN INDIAN LAW].

5. See United States v. Wheeler, 435 U.S. 313, 323 (1978) ("Indian tribes still possess those aspects of sovereignty not withdrawn by treaty or statute, or by implication as a necessary result of their dependent status.").

6. Cherokee Nation v. Georgia, 30 U.S. (5 Pet.) 1, 17 (1831) (describing the federal government as a "guardian" of tribes); accord AMERICAN INDIAN LAW, supra note 4, at 62.

7. See AMERICAN INDiAn LAW, supra note 4, at 62 (stating that tribes must "look to [the federal] government for protection" and "appeal to it for relief to their wants" (citing Cherokee Nation, 30 U.S. at 17)). 
property. Then, this Note will explain how existing legislation protecting tangible cultural property also fails to protect intangible cultural property, but shows the potential for new legislation. Finally, this Note will suggest legislative language aimed at facilitating negotiations between tribal governments and educational entities.

This discussion is not meant to be a comprehensive how-to guide, as needs will vary by tribe and educational entity. Instead, this Note is meant to add to the ongoing conversation by showing how digitization adds a new angle to this century-old problem.

I.

\section{BACKGROUND}

\section{A. The Significance of Cultural Property}

Cultural property encompasses a broad range of both tangible and intangible objects. ${ }^{8}$ Cohen's Handbook of Federal Indian Law defines cultural property as "any property of great importance to the cultural heritage of a people." ${ }^{9}$ For this Note, however, cultural property will more narrowly refer to intangible sacred traditional knowledge that has been fixed in a tangible medium, such as (1) photographs of tribal members on tribal lands, on sacred grounds, or using sacred resources; (2) written and transcribed field notes from anthropological visitors to tribal lands; and (3) sound and audiovisual recordings of intimate tribal affairs, including the recitation of creation stories, interviews with tribal members, and the performance of traditional dances and ceremonies.

Items like photographs, journals, and recordings pose a unique concern. Unlike items that fit the more colloquial definition of cultural property, ${ }^{10}$ such as baskets or pottery, the physical object itself is not the main cause for concern. Instead, the sacred nature of the object originates in the secrecy surrounding the information it contains. ${ }^{11}$ For example, Rebecca Tsosie pointed out that certain tribal songs and stories "may in fact have a sacred essence, they may have

8. Kristen A. Carpenter, Sonia K. Katyal \& Angela R. Riley, In Defense of Property, 118 YALE L.J. 1022, 1034 (2009).

9. COHEN'S HANDBOOK OF FEDERAL INDIAN LAW § 20.01, at 1267 (Nell Jessup Newton ed., 2012) [hereinafter COHEN'S HANDBOOK] (discussing the definition of cultural property under international law and providing examples of such property, including "monuments of architecture, art, or history, whether religious or secular, archaeological sites, and groups of buildings which, as a whole, are of historical or artistic interest, as well as scientific collections and important collections of books or archives or of reproductions of such property.").

10. See 25 U.S.C. § 3001(3)(D) (2012) (construing cultural property as tangible objects).

11. For more information and examples of how the sacredness of objects depends on when, how, and by whom they are used, see Traditional Knowledge (TK) Labels, LOCAL CONTEXTS, http://www.localcontexts.org/tk-labels [https://perma.cc/5LHY-L5VE]. 
spiritual value, so the harm's not merely economic, but it can be a cultural form of harm that could be very devastating.,"12

Indeed, sacred traditional knowledge is not merely information, it is essential to the tribal way of life. According to Robert Anderson, "Indian culture is ... not readily separable from religion, and both are integral to the identity of American Indian tribes." 13 Traditional tribal religions focus on "achieving harmonious relationships with all persons, other species, and the land" and affect all aspects of tribal life. ${ }^{14}$ This is not to suggest that all tribal religions are the same - since religious and cultural beliefs and practices are typically related to a tribe's home region, most religious and cultural beliefs are site specific. ${ }^{15}$ For many tribes, certain practices that could be captured in photographs, field notes, or recordings are sacred and not intended to be widely disseminated.

Despite these specific concerns, the legal system has been reluctant to protect intangible property. Congressional acts such as the Native American Graves Protection and Repatriation Act (NAGPRA) ${ }^{16}$ offer some protection for tangible cultural property but omit protection for the sacred traditional knowledge the object conveys. ${ }^{17}$ For example, while NAGPRA requires educational entities to repatriate the physical object, it does not protect against scans, replicas, or digital copies of the repatriated object. ${ }^{18}$ This omission is understandable: regulating information is an onerous task.

The omission of intangible cultural property protection is damaging; however, this omission is one page in a long book of federally sponsored, culturally detrimental policies. Congressional policies such as assimilation and removal have disrupted essential components of tribal life and removed tribes

12. Prof. Rebecca Tsosie: Current Issues in Intellectual Property Rights to Cultural Resources, NATIVE AM. RTS. FUND (June 25, 2017), http://www.narf.org/2017/06/tsosie-intellectual-property [https://perma.cc/DVU7-WVQT]; see also Rebecca Tsosie, Reclaiming Native Stories: An Essay on Cultural Appropriation and Cultural Rights, 34 ARIZ. ST. L.J. 299, 300 (2002) ("Cultural resources, both tangible and intangible, are of critical importance to Native peoples, because Native culture is essential to the survival of Indian Nations as distinctive cultural and political groups.").

13. AMERICAN INDIAN LAW, supra note 4, at 771.

14. Id.

15. See id.

16. See 25 U.S.C. $\S 3001(3)$ (2012). In 1990, Congress passed NAGPRA, which requires federally funded educational entities to repatriate objects that fall into one of the four protected categories: funerary objects, sacred objects, cultural patrimony objects, and human remains. For further discussion of the Act, see infra Part II.B.3.a.

17. This issue is reminiscent of the idea-expression distinction concept from copyright law. Copyright protection differentiates between the idea, which is not protectable and therefore usable by everyone, and its expression, which is protectable. See 2 MARK A. LEMLEy, PETER S. MENELl \& Robert P. MERges, Intellectual Property in the NeW TeChNOlogical Age: 2016, at IV-49 (2016). Similarly, NAGPRA differentiates between the intangible, sacred nature of the cultural property, or the idea, and its physical expression, or the object. Since NAGPRA only protects the physical expression, the sacred nature of the object remains exposed to exploitation. The disconnect between the needs of intangible cultural property and the scope of copyright protection is discussed in greater detail infra Part II.A.2.

18. See 25 U.S.C. $\S \S 3001-3003$ (2012). 
from their places of origin. ${ }^{19}$ For example, the Crow tribe currently resides in Montana on "a fraction of its former territory." 20 This loss of land has rendered the Crow unable to engage in many traditional rituals and amounts to "a form of cultural death." ${ }^{21}$ By removing tribes from their places of origin, the federal government actively cut ties between tribal culture and land, the latter of which is often intimately tied to a tribe's cultural practices and religious beliefs. ${ }^{22}$

In the mid-nineteenth century, Congress enacted laws banning spiritual practices, which further devastated tribal ways of life. ${ }^{23}$ These policies became broader and more prevalent throughout the late nineteenth and early twentieth centuries, eventually banning religious and cultural ceremonies, funeral procedures, and traditional hunting and fishing practices. ${ }^{24}$ This resulted in further devastation to tribal ways of life, as generations were unable to pass on traditions to the next generation. ${ }^{25}$

After centuries of policies that sought to either annihilate or assimilate tribes and their members, the federal government now subscribes to a policy of "self-determination." ${ }^{26}$ As a result, tribes are arguably better situated now than under previous government policies. Self-determination has allowed tribes to have a voice in policies that affect them; therefore, tribes currently have a greater ability to advocate for and receive cultural property protection. ${ }^{27}$ Many tribes have tried their own hand at protecting their cultural property. ${ }^{28}$ However, because educational entities possess the objects in question and often have access to more resources, collaboration between tribes and educational entities would arguably be a more effective way to protect cultural property. Although there is

19. See Carpenter et al., supra note 8, at 1091.

20. Sarah Krakoff, American Indians, Climate Change, and Ethics for a Warming World, 85 DENV. U. L. REV. 865, 881-82 (2008) (discussing how US environmental neglect has contributed to climate change, which has forced the Crow tribe off its sacred land, and emphasizing how US policies have negatively affected tribal ways of life by hindering the connection tribes have with their places of origin).

21. Id.

22. Carpenter et al., supra note 8, at 1075 ("In contrast to the Christian tradition, which emphasizes human dominion over land, non-Western and indigenous approaches to property imbue the land itself with a particular spiritual significance.").

23. AMERICAN INDIAN LAW, supra note 4, at 771.

24. Id.; see, e.g., DEP'T OF THE INTERIOR OFF. OF INDIAN AFFAIRS, CIRCULAR NO. 1665 (1921) ("The sun-dance and other similar dances and so-called religious ceremonies are considered 'Indian Offences' under existing regulations ....").

25. See AMERICAN INDIAN LAW, supra note 4, at 771-72.

26. Kevin K. Washburn, Tribal Self-Determination at the Crossroads, 38 CoNN. L. REV. 777, 779 (2006) (noting that both Richard Nixon's 1970 statement on federal Indian policy and the Indian Self-Determination Act of 1975 formalized the "self-determination era").

27. Carole Goldberg-Ambrose, Not "Strictly" Racial: A Response to "Indians as Peoples," 39 UCLA L. REV. 169, 184 (1991) ("Very simply, if Indians do not have a protected land base and some substantial measure of self-determination, Indian culture will fade and ultimately disappear.").

28. See Angela R. Riley, "Straight Stealing": Towards an Indigenous System of Cultural Property Protection, 80 WASH. L. REV. 69, 92-116 (2005). 
no way to reverse the effects of these harmful laws, taking steps to preserve what remains would be a good place to start.

\section{B. Digitization Efforts}

The threat of cultural property destruction has gained new urgency as educational entities consider digitizing their collections. Digitization will provide new and potentially limitless opportunities for exploitation of intangible cultural property. However, regulation of intangible cultural property need not completely erase sacred tribal knowledge from the public domain. Digitizing tribal cultural property could benefit both tribes and dominant society, so long as it is (1) a collective effort between tribal stakeholders and educational entities and (2) sensitive to the tribe's preferences and beliefs.

\section{Rationale}

Digitization of cultural property is a goal that extends beyond its impact on tribes in America. For decades, educational entities around the world have toyed with making their collections electronic. ${ }^{29}$ There are two main reasons why these entities wish to digitize their collections. The first is the theory of a "museum without walls;" the idea that people should be able to access information remotely. ${ }^{30}$ Second, these entities wish to protect cultural property against threats such as wartime destruction or natural degradation over time. ${ }^{31}$

In 1947, French Minister of Cultural Affairs André Malraux proposed the idea of a "museum without walls." technological capability at the time, would allow art to flow without geographic or temporal boundaries. ${ }^{33}$ In Technoheritage, Sonia Katyal suggested that "[t]oday's 'museum without walls' is . . made possible by the advent of digitization and 3-D reproduction technologies. Many museums are now digitizing their collections in order to offer greater access to the public . . ..,34

In 2009, for instance, the Smithsonian began scanning and digitizing pieces in its collection. ${ }^{35}$ Now, the museum's website allows users remote access to

29. See, e.g., Ethics of Exhibiting Culturally Sensitive Materials Online, SMITHSONIAN NAT’L MuSEUM OF NAT. HIST., http://anthropology.si.edu/naa/home/culturally_sensitive.html [https://perma.cc/2SFE-9WPD] (providing a bibliography of sources dating back to the late 1990s that have tracked the ethics of displaying cultural property electronically); see generally Werner Schweibenz, The Development of Virtual Museums, 3 ICOM NEWS (2004), http://cool.conservationus.org/icom/fileadmin/user_upload/pdf/ICOM_News/2004-3/ENG/p3_2004-3.pdf [https://perma.cc/4WGT-HLNA].

30. Sonia K. Katyal, Technoheritage, 105 CALIF. L. REV. 1111, 1116 (2017).

31. Id. Both rationales paint digitization as a much-needed solution, but fail to address the topic of cultural appropriation, which this Note will explore in the following Section.

32. Id.
33. Id.
34. Id. at 1117.
35. Id. at 1130. 
certain artifacts and the ability to view and rotate 3-D scans of the objects. ${ }^{36}$ One relevant example is the 3-D scan of a "Killer Whale Hat," a wooden sculpture made in 1900 by an artist from the Tlingit Dakl'aweidí, a clan in southeast Alaska. ${ }^{37}$ The 3-D scan shows the careful wood carvings, the intricately painted blue body with red and black accents, the abalone shell accents, and the black hair-like streamers. This level of detail offers amazing educational opportunities, but also shows just how intrusive this digitization process can be.

Another rationale for digitization is cultural preservation. This rationale is not novel but is rooted in an internationally held belief that cultural artifacts should remain intact during war or international conflict. ${ }^{38}$ Much as fighting siblings avoid their mother's crystal vase even during the heat of their brawl, this agreement about the sanctity of cultural artifacts preserves the integrity of such objects for future generations. If a state or rebel group does not play by the rules, technology now has the capacity to bandage the cultural wound.

This rationale has powerful proponents; Congress codified the aforementioned belief about the importance of cultural property. In April 2016, Congress passed the Protect and Preserve International Cultural Property Act. ${ }^{39}$ The Act expresses "the sense of Congress that the President should establish an interagency coordinating committee to coordinate the efforts of the executive branch to protect and preserve international cultural property at risk from political instability, armed conflict, or natural or other disasters. ${ }^{, 40}$ By codifying the aforementioned belief about the importance of cultural property, this Act supports endeavors of artists like Morehshin Allahyari, who is 3-D printing replicas of artifacts destroyed by the Islamic State of Iraq and Syria (ISIS). ${ }^{41}$

Not all degradation of cultural property occurs at the hands of humans. Natural elements such as light or damp air can damage older papers, films, and even the technologies used to listen to or view objects. Colorado State University's (CSU) “Preservation @ Work" project is one example of an entity's effort to battle natural degradation. CSU had posters and photographs in a library display case explaining its efforts to digitize, restore, and preserve its collection. The slogan "preservation . . . pass it on" appeared at the bottom of several posters. CSU purported to have created " 126,650 [d]igital images . . . since 2007"; added "10,000 rare books and hundreds of boxes . . . of primary resource

36. See, e.g., Smithsonian X 3D Beta Tlingit Dakl'aweidi Killer Whale Hat, SMITHSONIAN INSTITUTION, http://3d.si.edu/explorer?modelid=392\&reader=true [https://perma.cc/R9X5-MH7S].

37. Id.

38. Katyal, supra note 30 , at 1111.

39. See generally Protect and Preserve International Cultural Property Act, Pub. L. No. 114-151, 130 Stat. 369 (2016) (authorizing import restrictions to protect cultural property endangered by the Syrian Civil War); see also Katyal, supra note 30, at 1113-14 (discussing how the "obliteration" of cultural property influenced Congress to pass the Protect and Preserve Cultural Property Act in April 2016).

40. Protect and Preserve International Cultural Property Act $\S 2$.

41. Katyal, supra note 30 , at 1132. 
materials" to its collection; and repaired " 162,724 [v]olumes" in 27 years. $^{42}$ CSU's efforts reflect the dual rationale of digitization: preservation and remote access to information through Internet databases.

\section{The Intersection of Digitization and Tribal Cultural Appropriation}

Digitization and online reproduction provide exciting opportunities for people who might not otherwise have access to information and the arts. On the other hand, society tends to exploit marginalized groups by commodifying their culture while simultaneously excluding them from the benefits experienced by the dominant society. ${ }^{43}$ The use of technology exacerbates and perpetuates cultural appropriation. ${ }^{44}$

Tribes experience cultural appropriation in a variety of ways. For example, certain sacred sites have been subject to "cultural tourism," the phenomenon of people visiting other communities to learn about other cultures. ${ }^{45}$ Liza Keānuenueokalani Williams and Vernadette Vicuña Gonzalez, discussing the impact of cultural tourism on indigenous people of Hawaii, stated, "[T]ourismwith its discourses of invitation and its stratified economies of extraction-has smoothed over colonial occupation and its legacy of a racialized and classed society, producing a society that relies on the commodification of Hawai'i's land, history and culture." 46 Williams and Gonzalez also described how cultural tourism transforms indigenous culture into a Westernized commodity that often harms, rather than helps, indigenous communities. ${ }^{47}$ At its best, cultural tourism can provide a source of income for tribes and opportunities for collaboration, education, and mutual understanding between tribal and non-tribal members. ${ }^{48}$ At its worst, it can lead to unauthorized visits to sacred locations and

42. Posters in display case, "Preservation @ Work,” Colorado State University Morgan Library, (last visited Oct. 28, 2016).

43. See generally Rosemary J. Coombe, The Properties of Culture and the Politics of Possessing Identity: Native Claims in the Cultural Appropriation Controversy, 6 CAN. J.L. \& JURIS. 249, 249-50 (1993).

44. See Riley, supra note 28 , at 116 ("[T] echnology has only recently made possible the mass and immediate appropriation of indigenous peoples' intangible property.").

45. See, e.g., Dana Joseph, Looking for Native American Culture in the U.S.? Here's Where to Go, CNN TRAVEL (May 12, 2015), http://www.cnn.com/2014/04/15/travel/best-usa-indian-culture [https://perma.cc/MA6X-RBT5] (describing the best places in America to "experience" tribal culture).

46. Liza Keānuenueokalani Williams \& Vernadette Vicuña Gonzalez, Indigeneity, Sovereignty, Sustainability and Cultural Tourism: Hosts and Hostages at 'Iolani Palace, Hawai'i, $25 \mathrm{~J}$. SUSTAINABLE TOURISM, 668, 669 (2016).

47. Id.

48. See Natalie Lefevre, Cultural Tourism on South Dakota's Native American Reservations, ETHICAL TRAVELER (Sept. 5, 2013), http://ethicaltraveler.org/2013/09/cultural-tourism-on-southdakotas-native-american-reservations [https://perma.cc/JA3K-3PN9] ("By working together, the tribes aim to welcome visitors into their communities in order to educate them on their fascinating history and unique culture, and to share their hospitality and their authentic art."). 
unsanctioned mock ceremonies, possibly inspired by leaks of sacred information to non-tribal members. ${ }^{49}$

Technology provides another avenue for the exploitation of tribes. One popular culture example of this exploitation occurred at the 2004 Grammy Awards, when the music group OutKast performed their song "Hey Ya!" In this highly televised live performance, OutKast modified their original song to include the Navajo song "Beauty Way." ${ }^{50}$ As OutKast appeared on stage, emerging from a giant tipi while dressed in neon green grass skirts and feathered headbands, the sound of drums and chants boomed in the background. ${ }^{51}$ According to the President of the Navajo Medicine Man Association, "Beauty Way" is "'meant to restore peace and harmony,' and it is improper to use the song for entertainment purposes."

This exploitation was made possible through technological advancement; presumably, the initial Navajo drumbeat was recorded, taken back to a studio, amplified, and reproduced using either computer technology or mass-produced musical instruments. Then, the reproduction was recorded and played during the live televised show, which was transmitted to audiences around the country. And now, the exploitation has been digitized and uploaded to YouTube, where it currently has almost three hundred thousand views. ${ }^{53}$

Although this example may seem trivial, it is only one of many instances of cultural appropriation that significantly impacts the lives of Native Americans. When strung together, this type of cultural degradation helps to explain everything from the pervasiveness of mental health issues and the high suicide rate of Indian youth to the lack of financial resources available to the majority of smaller tribes. ${ }^{54}$ Cultural appropriation degrades the sanctity of certain

49. For example, Dr. Alfonso Ortiz was a Pueblo Indian anthropologist and a Pueblo Indian himself. His book THE TEWA WORLD: SPACE, TIME, BEING AND BECOMING IN A PUEBLO SOCIETY was controversial among Pueblo elders who claimed that it revealed sacred information. The Pueblo elders did not think non-Pueblo members should have access to this information. See generally George Johnson, Alfonso Ortiz, 57, Anthropologist of the Pueblo, Dies, N.Y. Times (Jan. 31, 1997), http://www.nytimes.com/1997/01/31/us/alfonso-ortiz-57-anthropologist-of-the-pueblo-dies.html [https://perma.cc/EFP5-TXHQ].

50. Riley, supra note 28, at 71.

51. Outkast - Hey Ya \{Live\} (FullHD), YouTuBE (Mar. 8, 2013), https://www.youtube.com/watch?v=iNUT0p0M0Nw\&app=desktop [https://perma.cc/8YDW-N7F8].

52. Riley, supra note 28, at 71 (quoting Jan-Mikael Patterson, Grammy TV Show's Use of Sacred Song Causes Outrage, NAVAJO TIMES, Feb. 12, 2004, at A-1).

53. OutKast, supra note 51.

54. See generally Let All That is Indian Within You Die!, 38 NATIVE AM. RTS. Fund LEGAL REV., Summer/Fall 2013, at 1 (quoting United States Assistant Secretary for Indian Affairs Kevin Gover: "The trauma of shame, fear and anger has passed from one generation to the next, and manifests itself in the rampant alcoholism, drug abuse, and domestic violence that plague Indian country. Many of our people live lives of unrelenting tragedy as Indian families suffer the ruin of lives by alcoholism, suicides made of shame and despair, and violent death at the hands of one another."); see also AM. PSYCHIATRIC ASS'N, MENTAL HEALTh DisParities: AMERICAN INDIANS AND ALASKA NATIVES (2010) (comparing the prevalence of mental illness in Native people to that of the United States as a whole and discussing some of the contributing factors); U.S. DEP'T OF HEALTH \& HUMAN SERVS., 
information for tribes, as well as demeans, dehumanizes, and invalidates the struggle of Native people. ${ }^{55}$ These examples underline the need for adequate legislative action aimed at limiting appropriation.

II.

ANALYSIS

Despite the harms that can be caused by misuse of cultural property, the existing legal framework provides no remedy for tribes or their members who have suffered harm from cultural appropriation. This Section will first explain why existing intellectual property laws ultimately fail to protect intangible tribal cultural property. This Section will then explain why laws protecting tangible tribal cultural property similarly cannot protect intangible cultural property, but still provide some guidance for how Congress can address this gap in the law.

\section{A. The Misfit of Existing Intellectual Property Protection}

IP laws are the most analogous form of intangible property rights in Western society, and thus provide a helpful framework for analyzing the need for intangible cultural property protection. This legal framework shows both the law's potential to redress cultural harms and its failure to protect intangible cultural property.

IP law, grounded in Eurocentric understandings of ownership, does not adequately protect intangible tribal cultural property. For this Note, intellectual property will mean the "creations of the mind, such as inventions; literary and artistic works; designs; and symbols, names and images used in commerce. ${ }^{, 56}$ IP protection finds its basis in the Constitution, which grants Congress the power "[t]o promote the Progress of Science and useful Arts, by securing for limited Times to Authors and Inventors the exclusive Right to their respective Writings and Discoveries," and has been codified in Titles 15, 17, 18, and 35 of the United States Code. ${ }^{57}$ Since IP law seeks to protect information, it might seem like a way to protect intangible cultural property. However, the diverging interests of IP law and tribes render the current laws insufficient.

AMERICAN INDIAN/ALASKA NATIVE BEHAVIORAL HEALTH BRIEFING BOOK (2011) ("This Briefing Book seeks to document the current efforts to address a range of serious behavioral health issues on a national, regional, and local basis.").

55. See Riley, supra note 28, at 78.

56. What is Intellectual Property?, WORLD INTELL. PROP. ORG., http://www.wipo.int/aboutip/en [https://perma.cc/W6F7-GZT7].

57. U.S. CONST. art. I, $\S 8$, cl. 8. Titles 15, 17, 18, and 35 of the United States Code govern trademark, copyright, trade secret, and patent laws, respectively. Certain states have attempted to provide further protection by enacting their own laws. Typically, however, where the laws conflict or are otherwise incompatible, federal systems of protection preempt state IP laws. See also Paul Heald, Federal Intellectual Property Law and the Economics of Preemption, 76 IOWA L. REV. 959, 961 (1991) ("An approach to federal intellectual property law sensitive to economics reveals that the Court invalidates only state laws that directly conflict with the operation of federal law."). 
In modern Western society, individuals and corporations are generally able to assert property rights over the things they invent, discover, create, or purchase. IP laws allow rights holders to regulate others' ability to use, reproduce, and create digital copies of their property. ${ }^{58}$ In exchange for these exclusive rights, rights holders share their creations with the public. This ensures that future artists and inventors can build off others' innovations, thereby advancing society. ${ }^{59}$

In Owning the Sun, Jill Koren Kelley suggested that cultural property remains unprotected because it is "frequently the direct result of cumulative knowledge." ${ }^{\prime 0}$ Such knowledge is formed by a "tradition of holders and creators who, through time, have created a particular body of knowledge." 61 In other words, a tribe collectively uses cultural property and therefore no individual owns the property in the Western sense of the word.

Here lies the flaw in trying to marry Western concepts of ownership with tribal ideas of property. The two are fundamentally incompatible because while the Western system is based on economically benefitting inventors and consumers, ${ }^{62}$ the tribal focus is largely on maintaining the cultural integrity of the group. ${ }^{63}$ To illustrate this point, Kristen A. Carpenter, Sonia Katyal, and Angela Riley drew on Margaret Jane Radin's personhood theory of property, which purports that certain types of property deserve higher levels of legal protection because they express individual personhood. ${ }^{64}$ The authors used the term "peoplehood" to describe the unique relationship between a tribe and its cultural property. ${ }^{65}$ Further, Carpenter, Katyal, and Riley stated that "[d]escriptively, the term 'people' connotes a collective association of individuals based on political affiliation, religion, culture, language, race, ethnicity, history, and other factors, while 'peoplehood' is the state of being a people or the sense of belonging to a people." ${ }^{, 66}$ The authors argued that certain

58. See U.S. CONST. art. I, § 8, cl. 8.

59. See What is Intellectual Property?, supra note 56 ("By striking the right balance between the interests of innovators and the wider public interest, the IP system aims to foster an environment in which creativity and innovation can flourish.").

60. Jill Koren Kelley, Owning the Sun: Can Native Culture Be Protected Through Current Intellectual Property Law?, 7 J. HIGH TECH L. 180, 187 (2007).

61. Id. (quoting Amina Para Matlon, Safeguarding Native American Sacred Art by Partnering Tribal Law and Equity: An Exploratory Case Study Applying the Bulun Bulun Equity to Navajo Sandpainting, 27 COLUM. J.L. \& ARTS 211, 215 (2004)).

62. 1 LEMLEY ET AL., supra note 17, at I-16.

63. See Kelley, supra note 60, at 188 ("The 'owners' of indigenous property may be the community in general, or a particular group of individuals (such as a family or clan). While intellectual property laws do provide protection for joint authors or owners, this is different from the concept of communal ownership as associated with cumulative knowledge.").

64. Carpenter et al., supra note 8, at 1046-47. An example of this is the difference between the value of a wedding ring to a jeweler and a spouse or a recipient of such a ring. To the spouse or recipient, the ring has symbolic value that goes beyond the monetary value of the precious stones or metals it is composed of. Id. at 1047.

65. Id. at 1028

66. Id. at 1053 . 
items of cultural property are so central to a tribe's identity, there is no logical way to commercialize, much less individualize, ownership. ${ }^{67}$

There are three main sources of IP protection: (1) trade secret, (2) copyright and patent, and (3) trademark law. In each of these systems, Western and tribal notions of ownership conflict. The following sections will explain why these regimes fail to properly protect intangible cultural property and why a new framework must therefore be developed.

\section{Trade Secrets}

Trade secret law protects secret or not-generally-known information that is valuable to an individual or business. ${ }^{68}$ In order to receive protection, a trade secret cannot be readily ascertainable by others and must be subject to reasonable efforts to be kept secret. ${ }^{69}$ In other words, there is an affirmative duty on the "secret holder" to refrain from sharing or allowing others to figure out the protected information. ${ }^{70}$ Protection for trade secrets was only recently codified in federal law and previously comprised a patchwork of state laws. ${ }^{71}$

Unlike copyrights or patents, trade secrets can be perpetually protected. ${ }^{72}$ While the perpetual nature of trade secret protection might seem perfect for protecting cultural property, it would be difficult for tribes to meet the minimum requirements. The threshold inquiry for trade secret protection is whether the information is profitable. ${ }^{73}$ One could argue that intangible cultural property is at least potentially profitable; for example, the Navajo tribe might suddenly record and sell copies of its song "Beauty Way." On the other hand, most tribes do not wish to commercialize sacred traditional knowledge. The very thing that makes certain aspects of traditional knowledge sacred is the information's limited use. By commercializing the information, the tribe would effectively be choosing to forfeit the cultural significance of the information.

Next, trade secret protection requires that the "secret" information not be readily ascertainable. ${ }^{74}$ However, many objects of intangible cultural property have already been exposed to the public. From recipes shared with outsiders to traditional uses of certain plants or places, techniques that are easily learned are

\footnotetext{
67. Id. at $1051-52$.

68. 1 LEMLEY ET AL., supra note 17, at II-9.

69. Id.

70. See id. at II-3 ("Failure to guard against disclosure of trade secrets by employees and contractors would jeopardize trade secret protection.").

71. Id. (noting that the Uniform State Trade Secrets Act runs concurrent with state trade secret protection).

72. Id. at II-7. Trade secrets are not subject to duration restrictions because the doctrine is meant to act as a minimum standard for "commercial morality" and fair business dealings, as opposed to an incentive to create. See id.

73. Id. at II-9 ("[T] he subject matter involved must qualify for trade secret protection," which covers "any valuable information [that is] capable of adding economic value to the plaintiff.").

74. Id. at II-8 (quoting UNIF. TRADE SECRETS ACT § (1)(4)(i) (1979) (UNIF. LAW COMM’N, amended 1985)).
} 
ineligible for trade secret protection. Revisiting the OutKast performance example, the Navajo drumbeat was allegedly overheard, learned, and then mimicked by an individual who attended a traditional Navajo ceremony. ${ }^{75}$ There, it would have been difficult for the Navajo to argue that their song was not "readily ascertainable" because tribal members played it openly for all to see and learn the rhythm and technique.

Last, the trade secret must be subject to reasonable efforts to maintain secrecy. ${ }^{76}$ Openly playing a noncomplex drumbeat in front of a large crowd in a public place likely would not qualify as maintaining secrecy. There are two separate issues here. The first and most basic issue is that no efforts were made to prevent others from learning or reproducing the drumbeat. Second-and more complicated - is the relationship between the tribe, its individual members, and the purported secret. Unlike a corporation that would typically require employees to sign nondisclosure agreements forming express confidential relationships, tribal members typically own information collectively. ${ }^{77}$ Therefore, it is not necessarily problematic for a tribal member to feel ownership over a piece of their culture; rather, it becomes problematic when an individual shares the information with an outsider, which in turn negatively affects the whole tribe. There is no remedy for appropriation of information that tribal members voluntarily shared; once these "secrets" enter the "public domain," they may not be retracted or protected by trade secret laws. ${ }^{78}$

The term "secret," as used in the context of trade secrets, is a product of individualistic and commercialized Western ways of thinking. By contrast, in most tribes, sacred knowledge is passed down to trained individuals, such as medicine men, who have earned the honor. Thus, it is not that tribes keep sacred information secret from other tribal members; rather, it is simply tradition to delegate the authority to a select few tribe members as opposed to the entire tribe. $^{79}$ Thus, the economic justification for trade secrets might help give businesses an edge, but it seems to be an imperfect fit for tribal use.

\section{Copyrights and Patents}

Both copyright and patent law seek to "promote the Progress of Science and useful Arts."

75. See Riley, supra note 28 , at 79.

76. 1 LEMLEY ET AL., supra note 17, at II-9 (“[T]he plaintiff, holder of the trade secret, took reasonable precautions under the circumstances to prevent its disclosure.").

77. Here, "own" means tribal members have knowledge of and respect for the tradition in question. It does not mean tribal members "have a commercialized property interest in" such information.

78. 1 LEMLEY ET AL., supra note 17, at II-3.

79. See Traditional Knowledge (TK) Labels, supra note 11.

80. U.S. CONST. art. I, $\S 8$, cl. 8 . 
protection include "incentive, labor-desert, and personhood" theories. ${ }^{81}$ The utilitarian justifications for copyright and patent protection purport that the best way to incentivize creation and contribution to the public domain is to provide limited protection to authors and inventors to profit from their creations. ${ }^{82}$ This is to say that copyright and patent protection is a means to an end - the point of allowing individuals to have exclusive rights over their creations is to encourage innovation that will continue to further the progress of humankind as a whole. Each of these philosophical justifications draws on the assumption that the best way to motivate independent creation is to monetize the value of the invention or other work.

Copyright applies to original works as soon as they are fixed in a tangible medium of expression. "Fixed in a tangible medium" is defined in 17 U.S.C. § 101 as the "embodiment [of a work] in a copy or phonorecord ... [where it can be] communicated for . . . more than transitory duration." ${ }^{, 4}$ Originality for copyright purposes is a fairly low bar, requiring only "a modicum of creativity." ${ }^{85}$ The author of the work owns the copyright and retains exclusive rights, including the rights to reproduce, perform, distribute, display, and make derivative works. ${ }^{86}$ Digitization implicates several of these exclusive rights, including reproduction and distribution. ${ }^{87}$

Copyright law does not provide protection for facts or information that are already in the public domain. ${ }^{88}$ Intangible cultural property like photographs, journals, and recordings can be conceptually divided into two parts. The first part is the factual knowledge about tribal life, which cannot receive copyright protection. The second part is the "selection, coordination, or arrangement" ${ }^{19}$ of these facts, which is protectable. For example, Alfonso Ortiz was an anthropologist who wrote a book about Tewa Pueblo culture and thus owns copyright in the creative way he communicated the information. ${ }^{90}$ Meanwhile,

81. Molly Van Houweling, Authors Versus Owners, 54 Hous. L. REV. 371, 377 (2016); see also 1 LEMLEY ET AL., supra note 17, at III-15 ("[T]he utilitarian framework serves as the central framework for most patent scholarship. This reflects the utilitarian character of the U.S. Constitution's Intellectual Property Clause ....”).

82. See Van Houweling, supra note 81, at 378.

83. Olivia J. Greer, Using Intellectual Property Laws to Protect Indigenous Cultural Property, 22 NYSBA BRIGHT IDEAS, no. 3, Winter 2013, at 30.

84. 17 U.S.C. $\$ 101(2012)$

85. See Feist Publ'ns, Inc. v. Rural Tel. Serv. Co., Inc., 499 U.S. 340, 346, 349, 357 (1991) (discussing how names and addresses placed in alphabetical order may not receive copyright protection, but how the "selection, coordination, or arrangement" of the information may receive "thin" copyright protection).

86. 17 U.S.C. $\S 106(2012)$.

87. See id.

88. See Feist, 499 U.S. at 357

89. Id.

90. See Johnson, Alfonso Ortiz, supra note 49. The article tells the story of an anthropologist who not only wrote about Tewa Pueblo culture but was also a Pueblo Indian. Many Tewa people felt that Ortiz leaked religious secrets and ostracized the author for his betrayal. Id. 
the Pueblo people do not retain an ownership interest in the book or the factual information reported about them. Further, because copyright law would prevent the unauthorized reproduction and distribution of the work, an educational entity seeking to digitize the work would likely need to obtain a license from Ortiz but would not need to notify the Pueblo people. ${ }^{91}$

The aforementioned Navajo song, "Beauty Way," is no longer eligible for copyright protection because it was created too long ago. ${ }^{92}$ So while it is not necessarily a fact, copyright law considers the song to be in the public domain and thereby freely usable by artists. OutKast's new adaptation of "Hey Ya!" is almost certainly copyrightable because it builds upon something that already exists, but it contains a "modicum of creativity" because it combines "Beauty Way" with original lyrics and music. ${ }^{93}$ OutKast therefore has the exclusive right to commodify and distribute the version of "Hey Ya!" including the portion of "Beauty Way," and the Navajo tribe lacks the legal recourse necessary to stop them. ${ }^{94}$ This outcome shows the tension between what should be freely accessible (and therefore in the public domain), and what should be protected as sacred knowledge. Because sacred traditional knowledge likely has a nearancient date of creation, it is likely part of the public domain and therefore generally not protectable. ${ }^{95}$

Patents are similar grants of exclusive rights but have more rigorous standards and a higher originality requirement. ${ }^{96}$ An inventor must go through the United States Patent and Trademark Office (USPTO) to attain patent protection. The USPTO will evaluate the validity of the patent application by checking to see if the invention meets the patentability requirements; in order to be patentable, the invention must be patentable subject matter, novel, useful, and non-obvious. ${ }^{97}$ If the invention meets these patentability requirements, the USPTO will issue a patent, which gives the inventor the exclusive right to keep

91. But see Authors Guild v. Google, Inc., 804 F.3d 202, 207 (2d Cir. 2015) (discussing how, although Google reproduced copyrighted works wholesale without a license, the search function and other features of Google Books was a "transformative use," such that no licenses were necessary).

92. See Riley, supra note 28 , at 80 .

93. See id. at 72 .

94. Id. at 78 (discussing how "the appropriation and distortion of indigenous peoples' intangible property . . . causes cultural devastation"). It is also likely that the Navajo people would not want to protect the song using the commercially driven copyright regime because commercializing the song would obviate the song's sacred nature.

95. This admittedly simplifies the issue. More accurately, traditional knowledge might be completely factual, and therefore not protectable (Plant $X$ does Action $Y$ ). Or, it might consist of a fact plus a unique "selection, arrangement, and coordination," but still might not be protectable, as the protectable duration might have expired (Plant $X$ does Action $Y$ when combined in this specific way with Plants $A, B$, and $C$, but the tribe has been performing Action $Y$ for five hundred years, well beyond the timespan for IP protection). $C f$. Feist Publ'ns, Inc. v. Rural Tel. Serv. Co., Inc., 499 U.S. 340, 357 (1991) (discussing the importance of the following in determining copyright eligibility: (1) the assembly of pre-existing fact; (2) the selection, coordination, or arrangement of the materials; and (3) the originality by virtue of this assembly).

96. See 1 LEMLEY ET AL., supra note 17, at III-20-III-21 (citing 35 U.S.C. § 102 (2012)).

97. Id. at III-9-III-10. 
others from using, making, selling, offering to sell, or importing the invention for twenty years. ${ }^{98}$ Because of the rigorous requirements for patent protection, intangible cultural property such as songs or photographs would generally be ineligible for patent protection.

The remedies available for patent and copyright holders when their rights are infringed reinforce the philosophical justifications for copyright and patent protection. These remedies typically include monetary damages or an injunction prohibiting defendants from making further unauthorized use of the work. ${ }^{99}$ As previously discussed, the commercial and utilitarian justifications for Western IP protection are not compatible with the needs of tribal cultural property protection. Monetary damages and injunctions that prevent "further use" of sacred traditional knowledge do not undo the harm that has already occurred when outsiders appropriate tribal cultural property. These inadequate forms of relief add to the complication of creating a uniform system of protection for cultural property. When the stakes are this high, no retroactive remedy seems adequate. What tribes truly need is a way to prevent or limit appropriation in the first instance.

\section{Trademark}

Trademark arguably offers the strongest tool to protect intangible cultural property, but ultimately does not provide sufficient protection. A trademark is a symbol used by an individual or a company in commerce to serve as a source identifier. ${ }^{100}$ Unlike copyrights or patents, trademarks are not designed to incentivize creation and do not "depend upon novelty, invention, [or] discovery." ${ }^{101}$ Rather, trademark protection is simply awarded to the first party to use a distinctive mark in commerce. ${ }^{102}$ Trademarks are designed to help prevent consumer confusion, incentivize product quality control, and make life easier on consumers by allowing them to easily identify the source of their goods and services. ${ }^{103}$ There are several different subcategories within trademark law ${ }^{104}$ and many different categories of protectable source identifiers. ${ }^{105}$ Rights of action for trademark misuse include infringement, dilution, false advertisements, and false description of origin. ${ }^{106}$ Unlike the protection provided to patented and

98. Id. at III-11.

99. 35 U.S.C. $\$ \S 283-284$ (2012). But see Ebay Inc. v. MercExchange, 547 U.S. 388 (2006) (holding that there are no automatic preliminary injunctions for patent infringement and remanding for the lower court to use the ordinary four-factor injunction analysis).

100. See 2 LEMLEY ET AL., supra note 17, at V-5.

101. See id. (discussing consumer protection as the policy rationale behind trademarks).

102. Id. (citing Trade-Mark Cases, 100 U.S. 82, 94 (1879)).

103. Id. at $\mathrm{V}-5-\mathrm{V}-6$.

104. This includes trade dress, service marks, collective marks, and certification marks. See id.

105. Id. (discussing protectable source identifiers as a word, phrase, design, image, sound, color, or smell).

106. Id. 
copyrighted works, trademark protection is not limited in duration. ${ }^{107}$ Trademarks may be protected so long as the mark is used in commerce. ${ }^{108}$

Certain tribes have tried using trademark law proactively as a way to protect their cultural property. Most famously, the Navajo tribe sued Urban Outfitters after the company used the tribe's name to sell certain items of clothing, such as apparel, jewelry, accessories, and flasks, under a "Navajo" product line that included geometric designs. ${ }^{109}$ Because the Navajo tribe has crafted and sold its own tribally affiliated goods, the tribe asserted trademark infringement and dilution claims. ${ }^{110}$ In response to the dilution claim, Urban Outfitters argued that the term "Navajo" was not "an enforceable trademark" because it is a generic term used to describe a certain style of clothing. ${ }^{111}$ The case has now settled, ${ }^{112}$ but in May 2016, the US district court in New Mexico held that the term "Navajo" is not "sufficiently famous" to be diluted by Urban Outfitters' usage and dismissed the trademark dilution claim. ${ }^{113}$ This case shows the difficulty faced by even the largest ${ }^{114}$ tribe when it comes to the protection of its cultural property.

The Zia tribe has also attempted to use trademark to protect its sacred sun symbol. The tribe claims the State of New Mexico appropriated and has maintained unauthorized use of the symbol since $1925 .{ }^{115}$ The State of New Mexico uses the sun symbol on its flag, license plate, and other products. ${ }^{116}$ The sun symbol has religious and cultural significance to the Zia tribe; however, because the tribe did not use the symbol for commercial purposes and because the symbol appeared on a state flag, the symbol was not eligible for trademark protection. ${ }^{117}$ Nonetheless, the tribe was able to leverage social pressure to convince certain entities to negotiate damages of sorts in the form of donations. ${ }^{118}$ While not entirely successful, the Zia's efforts are evidence that social pressure and negotiation might be enough to protect appropriated sacred

107. $I d$

108. Id. at $\mathrm{V}-5$.

109. Navajo Nation v. Urban Outfitters, Inc., 935 F. Supp. 2d 1147, 1154-55 (D.N.M. 2013).

110. Id. at $1153-55$

111. Id. at 1161,1166 .

112. Alysa Landry, Navajo Nation and Urban Outfitters Reach Agreement on Appropriation, INDIAN COUNTRY TODAY (Nov. 22, 2016), https://indiancountrymedianetwork.com/news/nativenews/navajo-nation-and-urban-outfitters-reach-agreement-on-appropriation $\quad$ [https://perma.cc/E8FMYAZ5].

113. Navajo Nation v. Urban Outfitters, Inc., No. 12-195 BB/LAM, 2016 WL 3475342, at *5 (D.N.M. May 13, 2016).

114. Urban Outfitters Handed Partial Victory in Navajo Case, FASHION L. (May 16, 2016), http://www.thefashionlaw.com/home/urban-outfitters-handed-partial-victory-in-navajo-case [https://perma.cc/CM72-6MHD].

115. Stephanie B. Turner, The Case of The Zia: Looking Beyond Trademark Law to Protect Sacred Symbols, 11 CHI.-KENT J. INTELL. PROP. 116, 116 (2012).

116. Id. at 121.

117. Id. at 122 .

118. See id. at 129. 
traditional knowledge, or at least to seek reparations where repatriation is impossible.

Trademark protection requires monetary and legal resources to register and enforce; the need for these resources may preclude certain tribes from attaining protection. Larger tribes like the Navajo and the Zia are more capable of obtaining trademark protection because of their relative affluence and their commercial use of their traditional symbols. Meanwhile, smaller tribes might lack the ability to commercialize or register their symbols, much less enforce their rights against infringers. Trademark's public disclosure requirement may pose additional barriers to protection. This type of publicity and exposure is the very consequence some tribes seek to avoid when information is sacred precisely because it is secret.

In addition to conventional trademark registration, the USPTO established a Native American Tribal Insignia Database in 2001. ${ }^{119}$ The database allows tribes to submit names, images, or symbols that the USPTO can then use to compare trademark registration applications. ${ }^{120}$ Individuals or businesses that attempt to register marks that are too close to a name, image, or symbol in the database will not be registered. ${ }^{121}$ While this system seems promising, it does not go far enough; it protects a very limited subset of tribal cultural property, namely a tribe's name and seal. Further, this system only prevents trademark registration, not any other types of use.

\section{B. Congressional Duty to Act}

Because Western IP laws have commercial and utilitarian justifications, it is difficult to square the needs of cultural property with the protections and remedies afforded. This Section will argue that Congress has an affirmative duty to fill this gap in the law. It will also discuss specific legislation enacted to protect tangible tribal cultural property. The policy justifications for protecting tangible cultural property provide a perfect springboard for protecting intangible property; however, these laws in their current state also fail to provide explicit protection for intangible items, such as images or songs.

\section{Defining Plenary Power}

Because of the special fiduciary relationship that exists between the federal government and tribes, Congress has both the duty and the authority to protect intangible cultural property. Plenary power is the idea that Congress, through the acquisition of the United States from the British, has the sole authority to

119. Press Release \#01-37, U.S. Pat. \& Trademark Off., USPTO Establishes Database of Official Insignia of Native American Tribes (Aug. 29, 2001), https:/www.uspto.gov/about-us/newsupdates/uspto-establishes-database-official-insignia-native-american-tribes [https://perma.cc/3Y8ZF8BS].

120. Id.

121. Id. 
regulate, treat with, and control tribes in its territory. ${ }^{122}$ According to an early seminal case, Johnson v. M'Intosh, Congress's power over tribes is derived from European conquest and America's subsequent independence from the British Crown. ${ }^{123}$ In another early case, Cherokee Nation v. Georgia, Justice John Marshall described Congress's power over Indian nations as the relation of "a ward to his guardian." 124 This is a paternalistic and somewhat confusing description since tribes are sovereign, yet they are being described as "domestic dependent nations." 25 Congress has used this expansive power throughout American history to enact laws and create policies that directly and detrimentally affect tribes - this often occurs without tribal consent and without regard for existing treaties. ${ }^{126}$

In recent years, Congress has moved from a period of predominantly paternalistic policy-making ${ }^{127}$ to an era of policy-making that encourages tribal "self-determination." 128 Congress used plenary power to pass laws and regulations that provide stronger protection for tribes and allow tribes to play a greater role in their own governance. Examples of major legal tools that have come out of this nexus of fiduciary obligation and self-determination include the Native American Graves Protection and Repatriation Act (NAGPRA), the Indian Arts and Crafts Act (IACA) (both discussed infra), and the Indian Child Welfare Act (ICWA).

\section{Plenary Power as a Tool for Cultural Protection: The Example of The Indian Child Welfare Act}

ICWA is particularly instructive for understanding how federal law can be harnessed to protect tribal culture. ICWA was enacted in collaboration with tribal government and provides a legal basis for rebuilding tribal culture. ICWA was passed in response to assimilative policies and actions taken by federal and state governments in the early twentieth century that left Native families splintered and fragmented. ${ }^{129}$ The boarding school era, for example, purported to "kill the Indian ... save the man." ${ }^{, 130}$ During this time period, school-aged children were

122. Johnson v. M'Intosh, 21 U.S. (8 Wheat.) 543 (1823). Cf. U.S. CONST. art. I, § 8, cl. 3.

123. Johnson, 21 U.S. at 587-88.

124. See Cherokee Nation v. Georgia, 30 U.S. (5 Pet.) 1, 17 (1831).

125. See id.

126. See, e.g., Cherokee Nation, 30 U.S. at 17; see also United States v. Kagama, 118 U.S. 375, 385 (1886).

127. See WiLLIAM C. CANBY, JR., AMERICAN INDIAN LAW IN A NUTSHELL 12-34 (5th ed. 2009) (providing an overview of the various policy eras in the US for "dealing" with Indian tribes, including colonization, removal, reservation, allotment and assimilation, reorganization, termination and relocation, and self-determination).

128. See id. (discussing the era of self-determination).

129. See Let All That is Indian Within You Die!, supra note 54.

130. Id. (quoting the founder of the Carlisle Indian School, Richard Pratt, whose stated goal "was to 'kill the Indian, in order to save the man'"). 
forced from their homes and placed in boarding schools. ${ }^{131}$ While attending boarding school, Native students were not allowed to observe cultural practices, wear traditional clothing or hairstyles, or even speak their own languages. ${ }^{132}$ Another alternative to boarding schools was the removal of children from their homes by social services under vague reasoning such as neglect. ${ }^{133}$ Native children were removed from their homes and reservations and usually placed with white families. ${ }^{134}$ These policies resulted in "lost generations," decimating tribal populations, language, and other traditions. ${ }^{135}$

Eventually realizing the detrimental effects on Native children and tribal culture, Congress passed ICWA in $1978 .{ }^{136}$ ICWA mandates that tribal courts have jurisdiction that is "exclusive as to any State" over child custody proceedings. ${ }^{137}$ ICWA also provides a hierarchy of where children should be placed, prioritizing placement with the child's tribe. ${ }^{138}$ Congressional rationale, enumerated in $\S 1901$, could be used to justify similar legislation to protect cultural property. ${ }^{139}$ ICWA in relevant part reads,

1) that clause 3 , section 8 , article I of the United States Constitution provides that "The Congress shall have Power $* * *$ To regulate Commerce *** with Indian tribes" and, through this and other constitutional authority, Congress has plenary power over Indian affairs;

2) that Congress, through statutes, treaties, and the general course of dealing with Indian tribes, has assumed the responsibility for the protection and preservation of Indian tribes and their resources .... ${ }^{140}$

This is an example of how Congress's fiduciary power-which has historically been used to marginalize tribes - could instead be used to empower tribes. The rationale behind ICWA provides an excellent framework for analyzing issues of cultural property; Congress affirms that it has a duty to protect and preserve tribes and their resources.

131. AMERICAN INDIAN LAW, supra note 4 , at $41-42$.

132. Id. at 487; see also H.R. REP. NO. 95-1386 (1978) ("To establish standards for the placement of Indian children in foster or adoptive homes, to prevent the breakup of Indian families, and for other purposes ...."); Let All That is Indian Within You Die!, supra note 54, at 1-9 (discussing how the Indian Boarding School Era inflicted cultural genocide and trauma on Native people, yet has been "written out of history books.").

133. AMERICAN INDIAN LAW, supra note 4, at 487.

134. Id.

135. See 25 U.S.C. $§ 1901$ (2012).

136. AMERICAN INDIAN LAW, supra note 4 , at 488.

137. 25 U.S.C. $\$ 1911$ (a) (2012).

138. Id. $\S 1915$. The Act mandates that the court should seek to place children first with a member of the "child's extended family"; next with a tribally approved or specified foster home; then with any Native foster home.

139. Id. $\S 1901$; see also id. $\S 3010$ (discussing how NAGPRA "reflects the unique relationship between the Federal Government and Indian tribes and Native Hawaiian organizations").

140. Id. § 1901 . 
Further, ICWA shows the impact tribal and congressional collaboration can have on the future of Native people. Keeping Native children with the tribe of course protects individual children, but also ensures that the children are able to participate in sacred tribal ceremonies and learn tribal traditions so that the traditions may continue. ICWA is an example of Congress supporting tribal governments' own preservation efforts. This same logic and framework easily justifies the need for intangible cultural property protection.

\section{Inadequacy of Existing Tangible Cultural Property Legislation}

This Section will discuss federal attempts at protecting tribal cultural property. These laws indicate an increasing trend in legislation providing cultural property protection, but existing laws tend to be narrower in scope and have their own specific limitations. Additionally, as mentioned, these laws only apply to tangible cultural property. Notably, although these laws do not protect intangible cultural property, the policy behind these laws - the fact that certain objects or places can be "integral and indispensable" to tribal culture-illustrates the idea that more than just tangible property deserves protection. ${ }^{141}$

\section{a. The Native American Graves Protection and Repatriation Act}

NAGPRA was enacted in 1990, and "establishes rights of Indian tribes and Native Hawaiian organizations, and their lineal descendants, to obtain repatriation of certain human remains, funerary objects, sacred objects, and objects of cultural patrimony from federal agencies and museums that are owned or funded by the federal government." ${ }^{142}$ NAGPRA also "protect[s] items that are located on or [found] within federal land or tribal land from unauthorized excavation or removal." "143 Finally, NAGPRA prohibits the "trafficking [of] Native American human remains and cultural items." " While NAGPRA is the most robust law for protection of Native resources, it does not address concerns about appropriation of intangible cultural property.

\section{i. Overview of Application}

NAGPRA requires federally funded educational entities to compile an inventory of tangible cultural property, such as human remains, associated funerary objects, items of cultural patrimony, sacred objects, and unassociated funerary objects. ${ }^{145}$ Further, the statute requires the museum to consult with

141. FRANK POMMERSHEIM, BROKEN LANDSCAPE: INDIANS, INDIAN TRIBES, AND THE CONSTITUTION 191 (2009).

142. COHEN's HANDBOOK, supra note 9, § 20.02[1][a], at 1271.

143. Id.

144. Id.

145. 25 U.S.C. $\S \S 3003,3004$ (a) (2012). For purposes of NAGPRA, "museum" is defined as "any institution or State or local government agency (including any institution of higher learning) that receives Federal funds and has possession of, or control over, Native American cultural items." Id. $\S$ 3001(8). 
"lineal descendants, tribal government ..., and traditional religious leaders."146 If the entity determines that an inventory item is culturally affiliated with a particular tribe, it must repatriate the item upon the request of the tribe. ${ }^{147}$

This duty to repatriate is subject to four exceptions: "scientific study, right of possession, competing claims, and takings of property." "148 These four limitations show the uphill battle toward repatriation that tribes tend to face even when the law is intended to help. For example, under the "'right of possession' exception," the tribe bears an initial burden to show that the government entity "does not have a right of possession." 149 The entity then has an opportunity to rebut the tribe's claims and "prove that it does" have the right of possession. ${ }^{150}$ Determining right of possession is a mixed question of law and fact; the entity would have a right of possession if "an individual or group with the authority to alienate the object" gave "voluntary consent" to its alienation, but the question of whether the conveyor had this authority "requires an inquiry into tribal law at the time of the alienation." 151

\section{ii. Repatriate-able Objects}

Under NAGPRA, museums must repatriate human remains and four other defined categories: "associated funerary objects," "unassociated funerary objects," objects of "cultural patrimony," and "sacred objects." ${ }^{152}$ None of the four categories are interpreted as protecting intangible cultural property, such as photographs, songs, or journal entries. Funerary objects are items that were "placed with individual human remains" "as a part of the death rite or ceremony." 153 The distinction between associated and unassociated funerary objects turns primarily on whether or not a museum or tribe has possession. ${ }^{154}$ Although NAGPRA regulates repatriation of funerary objects, it does not prevent a federally funded entity from making a digital copy (e.g. photograph or 3-D scan) of the items prior to repatriation. ${ }^{155}$

Next, "cultural patrimony" is defined under NAGPRA as "an object having ongoing historical, traditional, or cultural importance central to the Native American group or culture itself." 156 NAGPRA acknowledges the inherent

146. COHEN's HANDBOOK, supra note 9, § 20.02[1][c], at 1277.

147. Id.

148. Id. at 1278 .

149. See id.

150. Id.

151. Id.

152. 25 U.S.C. $§ 3001(3)(A)-(D)$ (2012).

153. Id.

154. Id. § 3001(3)(A)-(B). The nuances of this distinction are beyond the scope of this Note.

155. Jennifer Wiggins, Intellectual Property Rights: A Focus on Photography of Native Americans, 101 NEB. ANTHROPOLOGIST 1, 1 (1996).

156. 25 U.S.C. $\S 3001(3)(D)$ (2012). 
communal nature of tribal cultural property. ${ }^{157}$ Indeed cultural patrimony "cannot be alienated, appropriated, or conveyed by any individual regardless of whether or not the individual is a member of the Indian tribe." ${ }^{, 158}$ Thus, if cultural property was purportedly conveyed or transferred by an individual member of a tribe, the statute considers the object to have been wrongfully transferred because cultural patrimony is "considered inalienable" even "when it was separated from the group." 159

Courts have acknowledged that "[t]he key aspect" of cultural patrimony is "whether the property was of such central importance to the tribe or group that it was owned communally." 160 The Tenth Circuit in United States v. Corrow created a test for determining whether an object meets the definition of cultural patrimony:

[T]he object must have (1) ongoing historical, cultural or traditional importance; and (2) be considered inalienable by the tribe by virtue of the object's centrality in tribal culture. ${ }^{161}$ That is, the cultural item's essential function within the life and history of the tribe engenders its inalienability such that the property cannot constitute the personal property of an individual tribal member. ${ }^{162}$

Conceptually, intangible cultural property falls within this definition; sacred sites, songs, and stories are all items of central importance to tribes. Unfortunately, NAGPRA's definition of cultural patrimony fails to protect such intangible property. ${ }^{163}$ The purpose of NAGPRA is to repatriate items that are themselves necessary to physically enable ceremonies, ${ }^{164}$ not to maintain the privacy of tribal information. For example, a photograph depicting a sacred ceremony would not be protected under NAGPRA because the photograph itself is not of central importance to the ceremony.

Last, the definition of "sacred object" is seemingly broader than that of cultural patrimony, but still fails to encompass intangible cultural property. Sacred objects are "specific ceremonial objects which are needed by traditional Native American religious leaders for the practice of traditional Native American religions by their present-day adherents." ${ }^{, 165}$ While cultural patrimony describes

157. Kelley, supra note 60 , at 187 ("This occurs because both tangible and intangible forms of this cultural property [such as pre-existing motifs displayed in artworks, songs, dances, and folklore] 'are frequently the direct result of cumulative knowledge."').

158. See 25 U.S.C. $\S 3001(3)(D)$ (2012).

159. See COHEN'S HANDBOOK, supra note 9, § 20.02[1][b], at 1274.

160. Francis P. McManamon \& Larry V. Nordby, Implementing the Native American Graves Protection and Repatriation Act, 24 ARIZ. ST. L.J. 217, 233-34 (1992).

161. United States v. Corrow, 119 F.3d 796, 799-800 (10th Cir. 1997) (upholding a jury's conviction of Corrow for "illegal trafficking [of] cultural items" after concluding that "the Yei B'Chei constitute 'cultural patrimony' protected by NAGPRA").

162. Id.

163. See COHEN's HANDBOOK, supra note $9, \S 20.02[1][\mathrm{b}]$.

164. 25 U.S.C. $\S 3001(3)(D)$ (2012).

165. 25 U.S.C. $\S 3001(3)(C)$ (2012); 43 C.F.R. $§ 10.2(d)(3)(2015)$. 
objects that maintain ongoing significance, sacred objects includes objects "that were devoted to a traditional Native American religious ceremony or ritual and which have religious significance ... in the continued observance or renewal of such ceremony." 166 Although there must be "present-day adherents," this definition is seemingly less stringent regarding the maintenance of active, continuous usage through time. ${ }^{167}$ This definition leaves the "determination of continuing sacredness" to "Native American religious leaders themselves because they must determine the current ceremonial need for the object."168 NAGPRA reflects today's congressional policies encouraging tribal sovereignty by explicitly providing deference to tribal leaders.

Photographs of ceremonies or journals that include whereabouts of sacred sites could arguably be repatriated as sacred objects because the information contained in these mediums could help a tribe renew a ceremony. ${ }^{169}$ However, NAGPRA has not yet been interpreted this way. This is likely because the term "sacred objects," like "cultural patrimony," has been limited to tangible items rather than the information they contain. Accordingly, even if a sacred object is physically repatriated under NAGPRA, repatriation of the sacred knowledge contained in the object, such that it cannot be used by others, is not possible. ${ }^{170}$

As it stands, NAGPRA is an imperfect system for protecting sacred traditional knowledge. NAGPRA was a step in the right direction but has not evolved or been amended since its enactment. NAGPRA is limited in scope, as it cannot reach the contents of purely private collections; the Act applies solely to federally funded agencies and museums. ${ }^{171}$ Further, the Act applies only to objects that fit within one of the four categories of tangible items enumerated in the statute.

Despite its flaws, NAGPRA provides one of the federal government's most comprehensive and least paternalistic cultural property protection schemes to date. The Act encourages museums and federal agencies to consult directly with

166. 43 C.F.R. $\S 10.2(d)(3)$ (2015) (emphasis added).

167. Id.; see also Jack F. Trope \& Walter R. Echo-Hawk, The Native American Graves Protection and Repatriation Act: Background and Legislative History, 24 ARIZ. ST. L.J. 35, 65-66 (1992).

168. Trope \& Echo-Hawk, supra note 167 , at 66.

169. For example, tribes with oral traditions are especially vulnerable to a loss of certain traditional cultural practices. See Let All That is Indian Within You Die!, supra note 54, at 2 (describing how generations of children brought up in boarding schools would eventually return to their tribes lacking the "language, and cultural practices of those raised in their cultural context"). If an anthropologist studied a tribe and kept a field notebook detailing the specifics of a lost ceremony, the notebook could arguably be used to "renew" the ceremony by providing the next generation with instructions on how to perform the ceremony.

170. This situation could be likened to returning a book to the library-you return the book itself, but you retain the knowledge you learned from it. Similarly, NAGPRA requires federally funded museums to repatriate physical objects that qualify for protection but does not (and could not) protect the museum from retaining the information learned from the object.

171. 25 U.S.C. $\S 3001(8)(2012)$. 
tribes to create a repatriation plan for their cultural property. ${ }^{172}$ The Act also accounts for ownership disputes among tribes who share proximate origins, allowing the tribes the freedom to negotiate amongst themselves. ${ }^{173}$ Some tribes describe the NAGPRA process as slow and expensive; however, this is arguably the cost of the individualized nature of the process (or the result of a lack of compliance among museums and educational entities). ${ }^{174}$

\section{b. The Indian Arts and Crafts Act}

IACA was enacted in 1990 and prevents certain goods from being sold under false pretenses of Native affiliation. ${ }^{175}$ Similar to trademark law, IACA's primary purpose is to prevent consumer confusion regarding the good's source. ${ }^{176}$ Thus, the Act prevents manufacturers from falsely claiming that their goods are affiliated with tribes or produced by a tribal member. ${ }^{177}$ One section of the Act authorizes the creation and operation of the IACA board, which is tasked with "creat[ing] distinctive trademarks for Indian tribes and artists, and impos[ing] criminal and civil liability for those violating [the Act's] 'truth in marketing' provisions." ${ }^{178}$ For the purposes of the Act, an "Indian" is "either a member of any Indian tribe or someone who is certified as an Indian artisan by an Indian tribe." ${ }^{\prime 179}$ Thus far, IACA only addresses tangible goods, such as dolls, jewelry, clothing, rugs, pottery, and stone-carvings-items that are frequently imitated by non-Native affiliates. ${ }^{180}$ Certain companies who specialize in these types of goods have placed disclaimers on their website showing a good faith effort to prevent confusion. ${ }^{181}$

172. Id. § 3005(a)(3).

173. Id. $\S 3005(\mathrm{e})$.

174. While NAGPRA is admittedly imperfect, it is arguably better than omitting cultural property protection altogether. Where educational entities and museums are willing to cooperate, the process works well. NAGPRA does not currently have incentives for museums to comply —only sanctions and punishments if they refuse. An incentive-based structure would facilitate expedited negotiations and encourage compliance. See Frances Madeson, The Excruciating Legacy of NAGPRA, INDIAN COUNTRY TODAY (Mar. 31, 2016), https://indiancountrymedianetwork.com/history/genealogy/the-excruciatinglegacy-of-nagpra [https://perma.cc/955H-X8CU]; see also Carpenter et al., supra note 8, at 1097 ("For instance, controversy has ensued at the University of California, Berkeley, where the university's Phoebe A. Hearst Museum of Anthropology continues to resist the repatriation of the remains of some twelve thousand American Indians currently stored in archives beneath the Hearst Gymnasium swimming pool.").

175. AMERICAN INDIAN LAW, supra note 4, at 824.

176. See id.

177. Indian Arts and Crafts Act of 1990, Pub. L. No. 101-644, § 105, 104 Stat. 4662 (1990).

178. AMERICAN INDIAN LAW, supra note 4 , at 824.

179. Id.

180. See Indian Arts and Crafts Act of 1990, Pub. L. No. 101-644, § 105, 104 Stat. 4662 (1990).

181. See, e.g., Indian Arts and Crafts Act, PENDLETON, http://www.pendletonusa.com/custserv/custserv.jsp?pageName=Indian_Arts_And_Crafts_Act\&parentName $=$ CustomerServ ice [https://perma.cc/6D7T-8VAY]. 


\section{c. The National Historic Preservation Act and the Archeological Resources Protection Act}

In 1992, Congress amended the National Historic Preservation Act (NHPA) in the aftermath of the Supreme Court's decision in Lyng v. Northwest Indian Cemetery Protective Association. ${ }^{182}$ In that case, a group of Native Americans and environmental groups sued to enjoin construction of a forest road because it would severely hinder the Yurok, Karuk, and Tolowa in using the area for traditional religious ceremonies. ${ }^{183}$ Despite the area being an "integral and indispensable" part of tribal culture, the Supreme Court in a six-three vote held that construction of the road did not violate tribal members' First Amendment rights and allowed construction to proceed. ${ }^{184}$

After this negative outcome, tribes successfully lobbied for amendments to the NHPA. ${ }^{185}$ The Act now includes certain protections for "properties of traditional religious and cultural importance to an Indian tribe" 186 and has "prompt[ed] federal agencies to recognize and prioritize American Indian cultural and sacred sites." "187 It has also "provid[ed] Indian tribes a vehicle through which to participate in and monitor federal lands management."188

The Archeological Resources Protection Act (ARPA) is another source of protection for tangible property. ARPA was enacted in 1979 and "prohibits the excavation, removal, alteration or destruction of archeological resources from federal lands and 'Indian lands' unless a permit for removal has been issued.",189 The Act further requires consent from tribes and Native landowners to obtain an excavation permit. ${ }^{190}$

Despite the broadening protection of the NHPA and ARPA, intangible cultural property remains unprotected. Both laws apply only to tangible cultural property on federal lands. ${ }^{191}$ However, both NHPA and ARPA usefully illustrate that the significance attached to certain objects may be inalienable from tribal culture and, consequentially, from tribal existence.

As demonstrated above, current laws do not adequately protect intangible cultural property. Intellectual property laws and tangible cultural property laws fail to consider the unique needs of intangible cultural property, thus leaving them open to exploitation and reappropriation. Part III will discuss one possible

182. AMERICAN INDIAN LAW, supra note 4, at 824; Lyng v. Nw. Indian Cemetery Protective Ass'n, 485 U.S. 439 (1988).

183. Lyng, 485 U.S. at $442-44$.

184. POMMERSHEIM, supra note 141, at 190-92.

185. AMERICAN INDIAN LAW, supra note 4, at 824.

186. POMMERSHEIM, supra note 141 , at 195.

187. AMERICAN INDIAN LAW, supra note 4, at 824.

188. Id.

189. Id. at 823.

190. Id.

191. Id. at $823-24$. 
way to encourage educational entities to collaborate with tribes in an effort to protect intangible tribal cultural property.

III.

\section{PROPOSED SOLUTION}

Although existing laws fail to adequately balance the needs of tribes and educational entities, there are a limited number of examples indicating that educational entities and tribes can be incentivized to work together to reach agreements to reasonably accommodate their own needs. The Tlingit Dakl'aweidí Killer Whale Hat is one example of a positive outcome of individualized negotiations. The Smithsonian had possession of the hat, but was willing to work with the clan; according to the Smithsonian, "[t]he hat is both a sacred object and an object of cultural patrimony, which the National Museum of Natural History repatriated to the clan in 2005."192 Through negotiations between the museum and the indigenous clan, "[t]he hat was scanned with the clan's permission" and repatriated for ceremonial use. ${ }^{193}$ This negotiation allowed the museum to meet the dual goals of digitization: (1) the Whale Hat is now available to those who might not have physical access to visit a museum and (2) the scan serves as an "insurance against loss." the southeast Alaskan clan of indigenous people have shown the possibilities of an incentive-based negotiation scheme.

Protecting cultural property is a complicated task revealing not only a paradox between cultural property and intellectual property, but also a fundamental unease about stifling free speech and access to information. The constitutional right to free speech and our constitutionally based intellectual property system both seem to inherently oppose my proposition for stronger cultural property rights. For example, forbidding dissemination of an anthropological journal would seem to implicate (1) free speech concerns and (2) any property rights the author wished to retain in their creative work of authorship.

This opposition may erroneously assume that I argue for a complete ban of access to information about tribes. However, rather than having Congress enact laws completely banning access to tribal cultural property, Congress should instead lay the groundwork for individualized negotiations to solve the problem. By offering an incentive program (rather than motivation under threat of suit ${ }^{195}$ )

192. Killer Whale Hat, supra note 36 . The hat would likely be subject to repatriation under NAGPRA; however, NAGPRA would not apply to the digital replica. Accordingly, NAGPRA did not mandate that the Smithsonian negotiate with the tribe before scanning the object.

193. Id.; see Katyal, supra note 30, at 1152.

194. Killer Whale Hat, supra note 36 (discussing plans to replicate the whale hat using the 3-D scan as a blueprint).

195. NAGPRA's consequence-based structure (e.g., the statute allows tribes to sue for noncompliance under the Act, but provides no tangible, positive incentive for museums to comply) arguably makes the process "slow and expensive." See Madeson, supra note 174. By positively 
for educational entities to contact and negotiate agreements with tribes, and reallocating certain resources to tribes, Congress would be fulfilling its duty of tribal preservation as well as empowering tribes to self-determine cultural property protection.

It would be impossible, and incorrect, for Congress independently to create a uniform system of protection. The needs of each tribal community and each educational entity are unique. Even within a single tribe, certain intangible objects might require different permissions or restrictions; for example, a tribe might have restrictions requiring that certain songs only be performed during a certain time of year. ${ }^{196}$ Rebecca Tsosie underlines that, accordingly, "the system has to be expanded to take in to account the unique nature of these rights . . . a sui generis system . . . rights have to be crafted for the nature of the groups involved." 197

Thus, congressionally backed incentives would administratively be the easiest way to promote negotiations between the various entities and tribal governments. For example, Congress could offer a "voucher"-based system in which libraries and museums receive either federal funding or deeper tax breaks in exchange for negotiating with tribes for licenses prior to digitizing cultural property. This would incentivize the educational entities to make an effort to

incentivizing museums and other entities to act, and providing the financial means to do so, this proposal would reduce the costs to some degree. See also COHEN's HANDBOOK, supra note 9, § 20.02[1][e], at 1280 (describing NAGPRA's enforcement mechanism, which confers jurisdiction to federal district courts to hear suits by "any person alleging violation of the statute.").

196. See Traditional Knowledge, supra note 11 (proposing labels to accompany items in museum inventories that should only be displayed or performed seasonally); Katyal, supra note 30, at 1152-53. Katyal writes:

In other digital projects, many of which comprise websites that share culturally sensitive information, collaborating tribes have the power to curate, add to, and restrict the materials shared on the portal by tagging them as culturally sensitive. In a project with the Warumungu community, for example, anthropologist Kimberly Christen collected images that were divided into three categories: Open ("with "no limits placed on ... viewing"), Partially Closed ("reproduced with permission of those in the recording"), or Closed ("only to be viewed by people with proper ritual standing”).

Id.

197. Prof. Rebecca Tsosie, supra note 12 (explaining that the current Western IP system should be expanded to recognize sui generis rights, or the idea that "indigenous cultural expressions are a form of intellectual property and that traditional knowledge is a form of intellectual property, but they are collective resources"); see also Michael Davis, Indigenous Peoples and Intellectual Property Rights, PARLIAMENT OF AUSTL. RES. PAPER 20 (June 30, 1997), https://www.aph.gov.au/About_Parliament/Parliamentary_Departments/Parliamentary_Library/pubs/r p/RP9697/97rp20 [https://perma.cc/GW4T-BLMS]. Davis explains how:

$[t]$ he development of new sui generis legislative systems that provide recognition of the full range of Indigenous peoples' cultural products and expressions, and which enable community empowerment for the control of their cultures, is the only way to achieve a just solution to the problems faced by Indigenous peoples in the exploitation of their intellectual property rights. 
respect tribal knowledge. ${ }^{198}$ The money that the educational entities save on taxes (or that is distributed to them) under this program could go toward purchasing the licenses and paying a tribal member to act as a contracted consultant for the digitization project that would assist in correctly labeling, attributing, and explaining the significance of the licensed work. ${ }^{199}$

An example of possible statutory language follows:

1) Clause 3, section 8, article I of the United States Constitution provides that "The Congress shall have Power $* * *$ To regulate Commerce *** with Indian tribes" and, through this and other constitutional authority, Congress has plenary power over Indian affairs.

2) Congress, through statutes, treaties, and in the general course of dealing with Indian tribes, has assumed the responsibility for the protection and preservation of Indian tribes and their resources. ${ }^{200}$

3) Tribal Governments and Native Hawaiian organizations shall have limited rights to make, reproduce, sell, and distribute affiliated objects of intangible cultural property, ${ }^{201}$ subject to existing intellectual property laws.

4) Federally funded Libraries, Museums, and other educational institutions possessing or displaying objects falling under part (3) shall receive [a voucher/a certain percentage of additional federal funding/a certain percentage in tax breaks] upon notification and consultation with the appropriate tribal affiliates prior to using or continuing to use the objects.

5) Authors, artists, inventors, musicians, and other creators or inventors may similarly receive [a voucher/a certain percentage in tax breaks] where the individual attempts to notify, seek permission, or negotiate a license with tribal entities or Native Hawaiian organizations prior to incorporating Native intangible cultural property into the individuals own work.

198. Cost, time, and apathy act as the current barriers for repatriation and preservation of intangible tribal cultural property. Perhaps funding or tax cuts would help incentivize educational entities to act in spite of the current existing barriers.

199. This plan could be added as an amendment to the Protect and Preserve International Cultural Property Act.

200. This statutory language about the basis for Congressional authority is based on ICWA, see 25 U.S.C. $\S 1901$ (2012)

201. Intangible cultural property would be defined as:

an object, whether fixed in a tangible medium or passed on through oral tradition which has ongoing historical, traditional, or cultural importance central to the Native American group or culture itself, and which, therefore, cannot be alienated, appropriated, or conveyed by any individual regardless of whether or not the individual is a member of the Indian tribe or Native Hawaiian organization and such object shall have been considered inalienable by such Id.

Native American group at the time the object was separated from such group. 
6) $10 \%$ of any funds received by Libraries, Museums, and other educational institutions shall go to the governing body of a tribal government or Native Hawaiian organization that consults with, advises, and provides a renewable license(s) to the entity.

7) Where there is a dispute regarding ownership between tribes, all interested parties shall be notified in a timely manner, and each governing body of a tribal government or Native Hawaiian organization shall have 60 days to respond in writing to the notification.

8) Nothing in this Act shall prevent the governing body of a tribal government or Native Hawaiian organization from licensing use or reproductions of objects of intangible cultural property, or relinquishing control of such objects.

9) Nothing in this Act shall prevent the governing body of a tribal government or Native Hawaiian organization from filing suit against alleged infringers under any other scheme designed to protect intellectual or cultural property.

Under this scheme, tribes would control what information was disseminated and would have access to exactly what was being published about them.

Transaction costs might admittedly serve as a barrier to this system. With over 560 federally recognized tribes, a vast number of educational entities-each of which likely has shelves full of "hundreds of boxes" 202 of materials- the process would be slow and imperfect at first. Further, there are groups of Native people with distinct histories and cultural traditions that were removed from their ancestral lands, relocated to another area, and stacked next to other tribes. The movement and relocation mandated by the federal government has caused an extensive web of confusion when it comes to separating out cultural property. ${ }^{203}$ What happens if there are multiple tribes represented in one sound recording or photograph? What happens if one tribe wishes to receive payment in exchange for a license and another wishes to have the recording or picture repatriated? What if both wish for repatriation - should the object then be duplicated and a copy given to each, exacerbating the very trend we wish to avoid?

While these complications are valid counter points, NAGPRA provides guidance on how to address these concerns. If tribes - two sovereigns - are working to decide ownership amongst themselves, the duty to repatriate photographs, journals, and recordings will not attach until the tribes make a

202. “Preservation@ @ork," supra note 42.

203. Carpenter et al., supra note 8, at 1091 (discussing how the Indian Removal Period forced some tribes to leave their traditional burial grounds). This movement and relocation causes confusion today when tribes are forced to demonstrate that they are " $[t]$ he Indian tribe or tribes that are recognized as aboriginal to the area from which the human remains were removed," in order to show a possessory interest in the property. COHEN's HANDBOOK, supra note 9, § 20.02[1][c], at 1278-79. 
decision. ${ }^{204}$ In the interim, the educational entity would simply leave the object to the side until a decision is made. Although, similar to NAGPRA, the proposed process would be slow, it is certainly better than the current (nonexistent) scheme. Rather than digitizing based on murky permissions, this program would incentivize taking a step in the right direction.

\section{CONCLUSION}

The United States could lead the Western world in respecting tribal cultural property by creating a system in which tribes self-determine the fate of their cultural property. For two nearly decades, the US has participated in negotiations at the World Intellectual Property Organization (WIPO), but thus far, these negotiations have not resulted in new legislation. ${ }^{205}$ Notably, the recent United Nations Declaration of the Rights of Indigenous People discusses issues of cultural appropriation facing indigenous people globally. ${ }^{206}$ The declaration states, "States shall provide redress through effective mechanisms ... developed in conjunction with indigenous peoples, with respect to their cultural, intellectual, religious and spiritual property taken without . . consent . ...,207 This declaration shows that although there is no way to reverse the effects of these harmful laws, taking steps to preserve what remains would be a good place to start. If sui generis agreements between educational entities and tribes, like the one reached for the Tlingit Dakl'aweidí Killer Whale Hat, were the rule rather than the exception, American society, tribes, and Native people could mutually benefit.

204. See 25 U.S.C. $\S 3005(\mathrm{e})(2012)$

205. Prof. Rebecca Tsosie, supra note 12.

206. Id.

207. G.A. Res. 61/295, United Nations Declaration on the Rights of Indigenous Peoples, art. 11, cl. 2 (Sept. 13, 2007). 